\title{
Strategic guidance based on the concept of cleaner production to improve the ship recycling industry
}

\author{
Kanu Priya Jain ${ }^{1}$ (D) Jeroen Pruyn ${ }^{1}$ (D) Hans Hopman $^{1}$ (I)
}

Published online: 30 September 2017

(c) The Author(s) 2017. This article is an open access publication

\begin{abstract}
The implementation of international ship recycling regulations and international standards of health, safety and environment on a ship recycling yard improves environmental protection, occupational health and safety of the workers. However, it results in increased costs of the ship recycling process, which is detrimental for offering a high price to ship owners for buying end-of-life ships. In order to improve their competitiveness in the market, such "green" recycling yards, as they are generally called, must either increase the revenue or reduce the costs of the ship recycling process. Apart from this, being regulatory compliant, such yards must also plan the recycling process systematically. This paper aims to identify strategies that can help recycling yards achieve these objectives. The effective strategies are identified using the concept of cleaner production. It is chosen because it is a preventive environmental strategy that provides generic options to improve the financial and environmental performance of the production firms. The applied research method first establishes that the ship recycling process can be considered as a production process and then reviews each of the generic cleaner production options with respect to ship recycling. As a result, three strategies are identified, which
\end{abstract}

Kanu Priya Jain

k.p.jain@tudelft.nl

Jeroen Pruyn

j.f.j.pruyn@tudelft.nl

Hans Hopman

j.j.hopman@tudelft.nl

1 Department of Maritime and Transport Technology, Faculty of Mechanical, Maritime and Materials Engineering, Delft University of Technology, Mekelweg 2, 2628 CD Delft, The Netherlands are material flow analysis, design-for-recycling and wasteto-energy technology.

Keywords Ship recycling - Ship breaking - Cleaner production · Waste management $\cdot$ Ship scrap $\cdot$ Recycling yard

\section{Introduction}

The current state of the global ship recycling industry is such that the ship recycling yards processing end-of-life (EOL) ships responsibly in terms of damage to the environment and occupational health and safety of the workers are unable to offer a high price to ship owners selling obsolete ships. This is mainly due to high operational costs of such "green" recycling yards (Devault et al. 2016), as they are generally known in the industry (Sarraf 2010). On the contrary, recycling yards with no or little control over health, safety and environmental (HSE) impacts of recycling operations can offer a higher price to ship owners for buying EOL ships. Most ship owners prefer to sell their EOL ships to such "substandard" or "non-green" yards because their commercial interests are more important than HSE issues.

The term "green ship recycling" is not formally defined. However, several recycling yards around the world use this term to make themselves distinct from other yards. In general, the industry stakeholders agree that recycling a ship using the procedures defined by international ship recycling regulations such as the Hong Kong Convention (HKC) and EU Ship Recycling Regulation (EUSRR) can be called green. The main criteria to call a recycling facility "green" are explained in Chapter 3-Requirements for Ship Recycling Facilities of the HKC (IMO 2009) and 
Article 13- "Requirements necessary for ship recycling facilities to be included in the European List" of the EUSRR (EU 2013).

The difference in offer price is also related to the location of the yards. Amongst major recycling locations, which includes India, Pakistan, Bangladesh, China and Turkey, the yards located in the Indian subcontinent offer a higher price than the yards located in other parts of the world. This is due to the fact that the end-products generated by ship recycling facilities (SRF) in the Indian subcontinent are different from the end-products of the facilities located in Europe or China. The end-products of subcontinent facilities predominantly include steel plates, which are usually reconditioned as rerolled steel, whereas the end-products generated by other facilities include melting scrap having a much lower market value.

The only way for green recycling yards to augment their market share, irrespective of their location, is to improve their competitiveness by increasing the price they can offer to buy an obsolete ship. The offer price can be increased by increasing the revenues and/or reducing the costs of the ship recycling process. They must also plan the recycling process systematically to abide by the international regulations governing the ship recycling industry as discussed extensively by Hiremath et al. (2016). In essence, three critical issues that must be tackled by green recycling yards are increasing revenue, reducing costs and improving planning of the ship recycling process. Therefore, certain strategies which can be used to achieve such objectives must be identified.

Although several strategies can be applied, a logical approach is required to identify the effective strategies. The research conducted by Alkaner et al. (2006) concluded that the "planning, control and organisation of disassembly operations is a relatively new subject" and "identification of transferrable best practices from non-maritime industries would be beneficial". Therefore, this paper investigates whether the concept of cleaner production (CP), which is widely used by production firms to improve their competitiveness, can be used to achieve the goals of the green ship recycling yards.

The primary reason to investigate the concept of $\mathrm{CP}$ for its application to ship recycling is the fact that the process of recycling a ship closely resembles a production process because it involves transformation of inputs into outputs. "It is a one-of-a-kind production system where the inputs are the ship, labour and equipment (such as cranes, gas torches, fork lifts, etc.) which are transformed into outputs (such as ferrous scrap, non-ferrous scrap, re-usable items, waste, etc.) as a result of various processes, such as precutting, cutting and post-cutting" (Jain et al. 2017). The research carried out by Alkaner et al. (2006) also showed that ship recycling can be considered as a production system that supports the recovery, processing and resale of materials and components at the end of a ship's useful life. Another reason to study the concept of CP for its applicability to ship recycling is the fact that it is found beneficial by several authors (Cagno et al. 2005; Fresner 1998; López-Gamero et al. 2010; Tseng et al. 2006; Zeng et al. 2010) for improving the competitiveness, financial performance, environmental performance and operational efficiency of production firms.

The concept of CP is considered as a problem-solving strategy that leads to the solution, rather than a solution in itself (Lee 2001). Being a concept or general strategy, it could be applied to the ship recycling industry. Therefore, with the premises that ship recycling can be considered as a production system and CP can be applied to a production system to improve its competitiveness, this paper examines the applicability of various $\mathrm{CP}$ options to ship recycling. The article continues with the detailed background of the cleaner production concept followed by a methodology to apply the concept to the ship recycling industry. The result is the identification of a number of main strategies that are of potential interest to increase the economic viability of green ship recycling, compared to substandard recycling. The resulting strategies are applicable to various stages of a ship's lifecycle, from design, construction and operation to recycling. However, the aim is to provide benefits to the recycling stage.

\section{Background and methodology}

The awareness of the society regarding the environmental impact of the industrial activity started growing and spreading rapidly in the early 1960s (Cagno et al. 2005). The initial response to tackle the environmental problems arising due to the industrial activities was to control and treat pollutant emissions rather than finding ways to prevent emitting pollutants. This strategy was called as the "end-of-pipe" approach (Cagno et al. 2005). With more research in the field, soon it became clear that pollution prevention is always better than control and cure (Van Berkel 2000b), and environmental impacts must be seen from a product and process design point of view (Cagno et al. 2005). This led to the development of several approaches towards environmental management which include pollution prevention ( $\mathrm{P} 2)$, cleaner production $(\mathrm{CP})$, industrial ecology (IE), life cycle assessment (LCA) and eco-design (Cagno et al. 2005; Dieleman 2007). Out of these approaches, cleaner production is considered one of the most comprehensive, integrated, systematic and effective environmental management instruments as described in detail by Van Berkel (2000a). The reason is its flexibility to be applicable to all the processes and products, and its 
ability to provide solutions specific to each individual subject.

The term cleaner production was developed in 1989 by an expert working group as advice for Industry and Environment Program of United Nations Environment Program (UNEP) (Baas 1995). It was formally adopted by UNEP in 1990 and was defined as "the continuous application of an integrated preventive environmental strategy to processes, products, and services to increase overall efficiency, and reduce risks to humans and the environment" - and as applicable "to the processes used in any industry, to products themselves and to various services provided in society" (Larderel 2002).

Although the formal definition of $\mathrm{CP}$ approves its applicability "to the processes used in any industry", practically it finds applicability mainly to manufacturing/ production or service companies (Dodić et al. 2010). Glavič and Lukman (2007) further limit its applicability to production activities only, as they define CP as "a systematically organized approach to production activities, which has positive effects on the environment". According to Baas (1995), "it is a conceptual and procedural approach to production that fulfils the objective of prevention or the minimization of risks to humans and the environment during all phases of the lifecycle of a product or of a process".

The CP concept is based on the three main guiding principles, which are precaution, prevention and integration (Jackson 2002). These principles distinguish cleaner production from other environmental management strategies. The cleaner production strategy enables production and service companies to reduce their environmental impacts and risks to human beings from toxic materials (Dieleman 2007; Dodić et al. 2010; Lopes Silva et al. 2013). Besides this, it also helps in increasing their productivity by reducing the wastage of raw materials, energy and other resources, which in turn benefits them financially (Dodić et al. 2010; Van Berkel 2000b). Such environmental and financial benefits certainly indicate that $\mathrm{CP}$ can be useful in meeting the objectives of this research.

In this article, an in-depth analysis is carried out to apply the $\mathrm{CP}$ concept to ship recycling. A two-step methodology is used to undertake such analysis. The first step is to carry out a detailed study of the concept of cleaner production and its benefits. The second step is to assess the applicability of cleaner production to ship recycling and to generate appropriate strategies to meet the objectives of this research. This second step results in providing several strategies that may be used within the context of ship recycling. Such strategies are further analysed, and their usefulness to achieve the objective of this research is discussed.

\subsection{Cleaner production concept}

Cleaner production is a very broad concept that provides generic options which can be used to develop appropriate strategies (Van Berkel 2000b). The joint global cleaner production programme established in 1994 by the United Nations Industrial Development Organization (UNIDO) and the United Nations Environment Programme (UNEP) indicates that the following generic options can be used to apply the concept of CP (UNIDO-UNEP 2010).

1. Good housekeeping,

2. Input material change,

3. Better process control,

4. Equipment modification,

5. Technology change,

6. On-site recovery/reuse,

7. Production of useful by-products, and

8. Product modification

These options are depicted in Fig. 1.

The generic CP options are classified by El-Haggar (2007) into three main categories-reduction at source, recycling and product modification. The reduction of waste at source can be achieved by good housekeeping and process change. The change in process can be carried out by input material change, process control, equipment modification and technology change. The second main category-recycling-can be divided into on-site recycling and off-site recycling (to produce useful by-products).

Further, UNIDO-UNEP (2010) describes that good housekeeping means keeping provisions in place to prevent leaks and spills and to achieve standardized operation and maintenance procedures and practices. The option of input material change refers to replacement of hazardous or nonrenewable inputs by less hazardous or renewable materials or by materials with a longer service lifetime. The next three options, namely better process control, equipment modification and technology change, aim to modify the production process, equipment or technology in order to minimize the waste and emission generation during production. The option of on-site recycling or on-site recovery and reuse means reusing the wasted materials in the same process or for another useful application within the enterprise. The production of useful by-products is aimed at transforming the previously discarded wastes into materials that can be reused or recycled for another application outside the company. The last option, product modification implies modifying the product characteristics to minimize the environmental impacts of the product during or after its use or to minimize the environmental impacts of its production. 


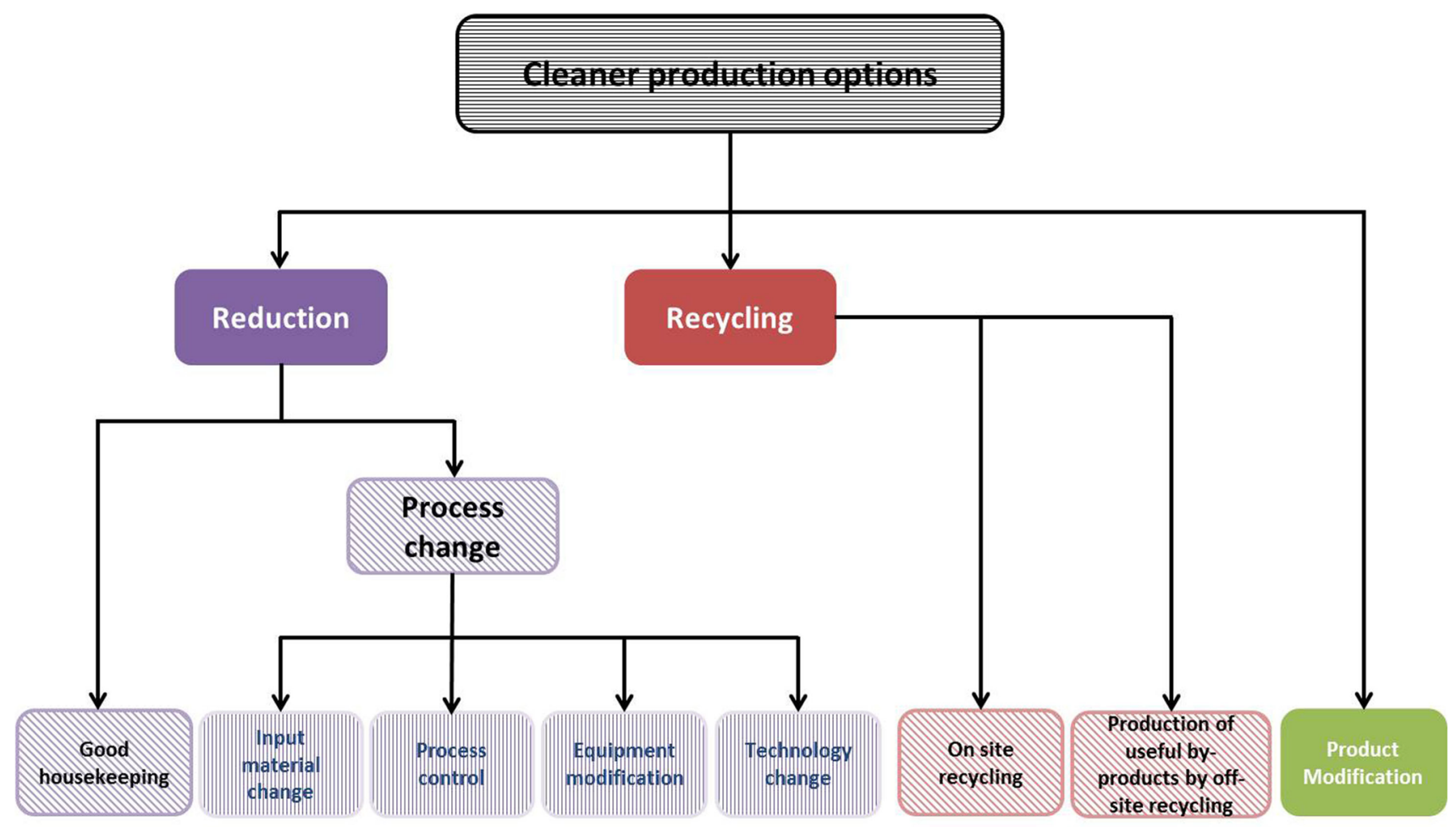

\footnotetext{
Solid fill indicates Level 1 of the classification

Diagonal pattern fill indicates Level 2 of the classification

Vertical pattern fill indicates Level 3 of the classification
}

Fig. 1 Generic cleaner production options Source: Author based on El-Haggar (2007)

\subsection{Benefits of cleaner production}

On a production firm, the main focus of cleaner production is to reduce waste generation at its source and to reduce the consumption of raw materials, energy and other resources by optimizing both the products and the processes (Severo et al. 2017). On the one hand, this results in producing goods with minimum environmental impact and reduced pollution (Nilson et al. 2007), while on the other hand, it also helps in improving productivity, profitability and competitiveness of a firm (Dorfman et al. 1993; Nilson et al. 2007). These improvements are mainly due to increased savings in material costs (Van Berkel 2000b) and waste-associated operating costs (Baas 1995; Lopes Silva et al. 2013). The optimized waste treatment, recycling and disposal due to the application of cleaner production options (Lopes Silva et al. 2013) result in reduced expenses for treatment and disposal of wastes and emissions (Van Berkel 2000b), which further reduces the operating costs.

An incomprehensive literature survey finds several studies suggesting economic benefits of applying cleaner production to production companies in various countries such as Lithuania (Kliopova and Staniskis 2006), Slovenia (Petek and Glaviç 2000), Serbia (Dodić et al. 2010), Australia (Van Berkel 2000b), Norway (Kjaerheim 2005), India (Unnikrishnan and Hegde 2007) and Brazil (Severo et al. 2017). The questionnaire-based statistical analysis of 125 Chinese companies representing various industries (metal, heavy machinery, petroleum, chemical, pharmaceutical, paper, rubber and plastics) also showed a positive impact of cleaner production on the business performance of the companies (Zeng et al. 2010). Similarly, Cagno et al. (2005) documented the savings generated by 134 companies relating to multi-nations and multi-sectors, as a result of reduced operating costs due to the use of pollution prevention (P2) approach, an approach considered equivalent to CP (Jackson 2002). Most economic benefits arise due to the savings in operating costs as a result of reduction in the costs of raw materials, waste disposal and pollution abatement.

The environmental benefits of applying cleaner production can definitely be seen in the form of reduced waste generation and minimized pollution of all forms including air, water, soil and noise. Fresner (1998) described how 
organizations can install an effective environmental management system using cleaner production. The contribution of $\mathrm{CP}$ in the sustainable development of modern societies (Bonilla et al. 2010) and tourism (Lee 2001) is also well explained in the academic literature.

In addition to the economic and environmental benefits, CP can help organizations achieve other internal and external benefits (Dorfman et al. 1993; Lopes Silva et al. 2013). The internal benefits include lower absenteeism, improved productivity and personal satisfaction of workers due to improved occupational health and safety conditions (Lopes Silva et al. 2013). The external benefits include reduced liability risks, better relationships with the stakeholders, improved company image, increased market share and reduced health risks to the population in the vicinity (Lopes Silva et al. 2013).

Based on the benefits to the firms using cleaner production it can be clearly inferred that the use of CP can assist in achieving the objectives of this research and improving the ship recycling industry in general. The improvement in the business and environmental performance of the production firms is mainly due to the rational use of natural resources as a result of efficient material and energy flow management (Fresner 1998). However, in case of a ship recycling yard no natural resources or raw materials are used. Instead, an EOL ship, which is a finished product, acts as a resource. Therefore, the CP approach must be modified accordingly.

\section{Results and discussion}

\subsection{Cleaner production in the context of ship recycling}

The application of cleaner production to ship recycling can be justified by various reasons. First, the formal definition of cleaner production suggests that this approach is applicable to all industrial processes; second, the extensive use of $\mathrm{CP}$ in various industries for improving economic and environmental performance suggests its versatility; third, the similarity of ship recycling to a production system, a field where CP finds most applicability; and fourth, the fulfilment of objectives similar to that of this research by other industries using cleaner production.

The fact that the concept of CP can be applied to a process is also interesting from the perspective of a ship recycling yard because the recycling process affects the environment to a greater extent than the products that are created as a result of ship recycling. For green ship recycling, CP can help in reducing costs, improving revenues and planning the recycling process, while for ship recycling industry in general it can also be useful in reducing the environmental impacts.

Cleaner production is achieved by applying expertise, improving technology and changing attitudes (Baas 1995). However, the result or the improvement depends on the level of technology as well as on how CP is applied into everyday processes and aspects of recycling activities on a ship recycling yard. It is rightly pointed out by Jackson (2002) that developing an operational strategy on the basis of cleaner production principles is highly dependent on "sector-specific and application-specific parameters". Therefore, each one of the generic CP options discussed earlier is evaluated below for its applicability to the ship recycling industry.

\subsubsection{Good housekeeping}

The option of "good housekeeping" is generally aimed at reducing the wastage of input materials by means of prevention of leaks and spills. In case of ship recycling, preventing the wastage of input material, i.e. ship, is not the main goal. However, prevention of spills and leaks during the ship recycling process can be useful in impeding the environmental hazards posed by dismantling of ships.

The enforcement of the Hong Kong Convention (HKC) and EU ship recycling regulation (EUSRR) will help recycling yards to achieve good housekeeping as a result of mandatory ship recycling facility plan (SRFP) and ship recycling plan (SRP). It is because of the fact that SRFP must include procedures for spill prevention, control and countermeasures to prevent inadvertent spills and leaks inflicting adverse effects on the environment (IMO 2009, 2012).

\subsubsection{Input material change}

The main input material for the ship recycling process is a ship. The ships sold for recycling at the end of their economic lives invariably contain one or the other hazardous material. This includes asbestos, PCB, heavy oil, sludge, ozone-depleting substances, heavy metals and other similar materials. These hazardous materials, together with the complex structure of the ship, pose hazards to human health and safety as well as to the environment during recycling.

Ship recycling yards can control neither the complexity of a ship nor the hazardous materials it contain. However, new ships can be built in such a way that they do not pose risks to environment, human health and safety during recycling. This concept of designing and building products that are easier and environmentally sound to recycle is called as "design-for-recycling". It has been successfully reviewed by several researchers for applying on various 
products, but very few have explored the possibility of applying it on ships. For example, Ferrão and Amaral (2006), Soo et al. (2015), Tian and Chen (2014) and van Schaik and Reuter (2004) discussed its applicability on automobiles, Durham et al. (2015) discussed its applicability on clothing, Kuo (2010) examined its usability to improve the recyclability of waste electrical and electronic equipment (WEEE), whereas Perry et al. (2012) applied the concept to composites. The studies discussing the concept in the context of ship recycling include Alkaner et al. (2006), McKenna et al. (2012) and Sivaprasad and Nandakumar (2013) before being discussed and applied on a case ship by the authors of this paper in Jain et al. $(2015,2016 a)$.

\subsubsection{Better process control}

The option of "better process control" is aimed at modifying the production process to achieve better control on the discharges, emissions and waste generation. Its success depends on understanding and analysing the process. Therefore, a process mapping tool can be helpful in understanding the generic ship recycling process and identifying the problem areas that can be targeted not only to develop and make green ship recycling competitive but also to improve the ship recycling industry on the whole.

The objectives of this research effectuate the flow of materials on a ship recycling yard as the most critical flow of the ship recycling process. The rationale behind this is the influence of material composition of a ship on the revenue generation and the cost factors of a ship recycling project. The cost factors include the amount of resources (labour, cranes, forklifts, etc.) required to dismantle a ship, the amount of waste and its management strategy. Therefore, the material flow analysis (MFA), an analytical tool used in environmental engineering, which focuses on analysing the flow of materials within a system, is considered ideal for analysing and improving the ship recycling process. It is discussed by authors in detail in Jain et al. (2017).

The control of the ship recycling process is challenging because the current procedures and practices of the industry are such that the process input, i.e. a ship, has a very high uncertainty in terms of the composition of the materials it contains. This makes the planning of the recycling process very difficult. The quantification of materials (Jain et al. 2016b) and the material flow analysis (Jain et al. 2017) are the first few steps towards a better control of the ship recycling process.

\subsubsection{Equipment modification}

The option of "equipment modification" branches out of the option "process change" and is aimed at reduction of waste at source. The underlying objective of equipment modification is to ensure production processes run at higher efficiency and lower rates of waste and emission generation. The ship recycling yards can apply this approach to modify or change the recycling equipment with more efficient and less emitting equipment. For example, yards employing oxy-acetylene gas torches for cutting the ship's hull into smaller pieces can investigate the use of cold cutting methods such as water-jet cutting to avoid emissions of harmful gases during the cutting operation.

\subsubsection{Technology change}

The "technology change" option of cleaner production is also aimed at changing the process to reduce the waste generation at source. On a ship recycling yard, generation of waste depends mainly on the downstream markets for materials/components and the costs of recovering materials/components from an EOL ship. The change in technology will not affect the amount of waste generated to a great extent except for cases where new technology can reduce the material recovery costs. More importantly, new technology such as waste-to-energy technology can be used to turn waste into new products.

The usual practice on a typical ship recycling yard for managing the waste generated by dismantling EOL ships is to contract waste management companies for eliminating the waste. This kind of waste management strategy results in expenses for the ship recycling yards. To counter such expenses, yards may use a proven waste-to-energy technology to convert waste into energy and other useful products and sell them to generate revenue. However, technical and economic feasibility of such a technology must be undertaken to decide on its applicability to a ship recycling yard. The economic feasibility analysis of the plasma gasification technology on a large ship recycling yard (annual recycling capacity of 1 million tonnes) carried out by Jain and Pruyn (2016) shows that return on such investment can become positive within 10 years of the plant operation.

\subsubsection{On-site recovery and reuse}

The "on-site recovery and reuse" option of cleaner production is aimed at recycling and reusing the input material within the production process as much as possible. This option is more suitable to the production processes where there is a possibility of using waste as an input to the production process. For example, "own arisings" or 
"circulating scrap" which arise internally in steel mills as rejects from processes such as melting, casting and rolling can be reused within the steel mill.

On a ship recycling yard, there is no waste that can be used internally within the yard processes directly. However, the ability of a ship recycling yard to convert waste into a product that is used quite a lot (e.g. energy) might be beneficial. Using a waste-to-energy plant, the yard can utilize the energy produced from such a plant to run the yard equipment. A comparative analysis of benefits from selling energy and using it within the yard may still be required to take an informed decision.

\subsubsection{Production of useful by-products}

The cleaner production option of "production of useful byproducts" is aimed at recycling or reusing the by-products of the production process in an application outside the production plant. The by-products of an industrial process are often pollutants, or they are discarded as waste. However, use of such by-products from one industrial plant by another plant supports sustainability by means of industrial symbiosis. The most famous example of such industrial symbiosis is Kalundborg Industrial Symbiosis Complex in Denmark (Jacobsen 2006).

On a ship recycling yard, a major product that is discarded is the waste generated during the ship recycling process. The production of by-products which can be reused or recycled by other applications outside a ship recycling yard can be a useful strategy to minimize waste and prevent pollution resulting from the ship recycling process. This can be achieved by converting waste into energy and other useful products by using an advanced waste-to-energy technology. However, which material is considered waste differs from yard to yard depending on the technology and recycling process employed by the yard, local and international regulations applicable, downstream market and economic feasibility of extracting useful materials. A waste-to-energy plant suitable to the type of waste generated on a particular yard must be analysed for economic and technical feasibility before using such a technology.

In general, the following material streams originate from the ship recycling process (Jain et al. 2016b).

1. Ferrous scrap

2. Non-ferrous scrap

3. Machinery

4. Electrical and electronic equipment

5. Minerals

6. Plastics

7. Liquids, chemicals and gases

8. Joinery

9. Miscellaneous

\subsubsection{Product modification}

The last generic option of the cleaner production concept is "product modification". It is aimed at minimizing the environmental impacts of a product during all phases of its lifecycle, which includes production, use and recycling. In case of ship recycling, steel scrap is the main product which is generally used to produce new steel products either by reprocessing or melting. This consumes less energy than the normal procedure of producing steel products from raw materials. Therefore, there is not much scope of reducing environmental impacts by product modification. However, this option brings a different perspective to the ship recycling industry, which is described subsequently.

A ship recycling yard generally produces two main types of products, i.e. reusable products and recyclable products. The main products of a ship recycling yard include ferrous scrap and non-ferrous scrap within the recyclable products category and items such as machinery, motors, furniture and used oil within the reusable products category. The rest of the materials obtained from the ship's hull are generally discarded as waste due to the unavailability of market demand. This includes hazardous materials such as asbestos, PCB and ozone-depleting substances and other materials which cannot be sold in the downstream markets for reuse or recycling.

The types of products in demand differ from one country to other depending on the local regulations and product usability. Therefore, ship recycling yards must modify their products according to the market demand and conditions. For example, the steel (ferrous) scrap obtained from a ship can be classified into six categories, i.e. rerollable scrap, reusable scrap, rollable scrap, bar and shape steel, solid pillar and cast iron (Sujauddin et al. 2017).

\subsection{Discussion}

The results obtained by the evaluation of the generic cleaner production options with respect to ship recycling are summarized in Fig. 2. The evaluation resulted in finding several strategies that are applicable to the ship recycling industry. These include the following:

1. Using the procedures of HKC such as developing a ship recycling facilities plan and ship recycling plan.

2. Using the concept of design-for-recycling for building new ships.

3. Optimizing the ship recycling process using the analytical tool-material flow analysis (MFA).

4. Using better recycling equipment to improve efficiency of the recycling process and reduce emissions and waste generation. 


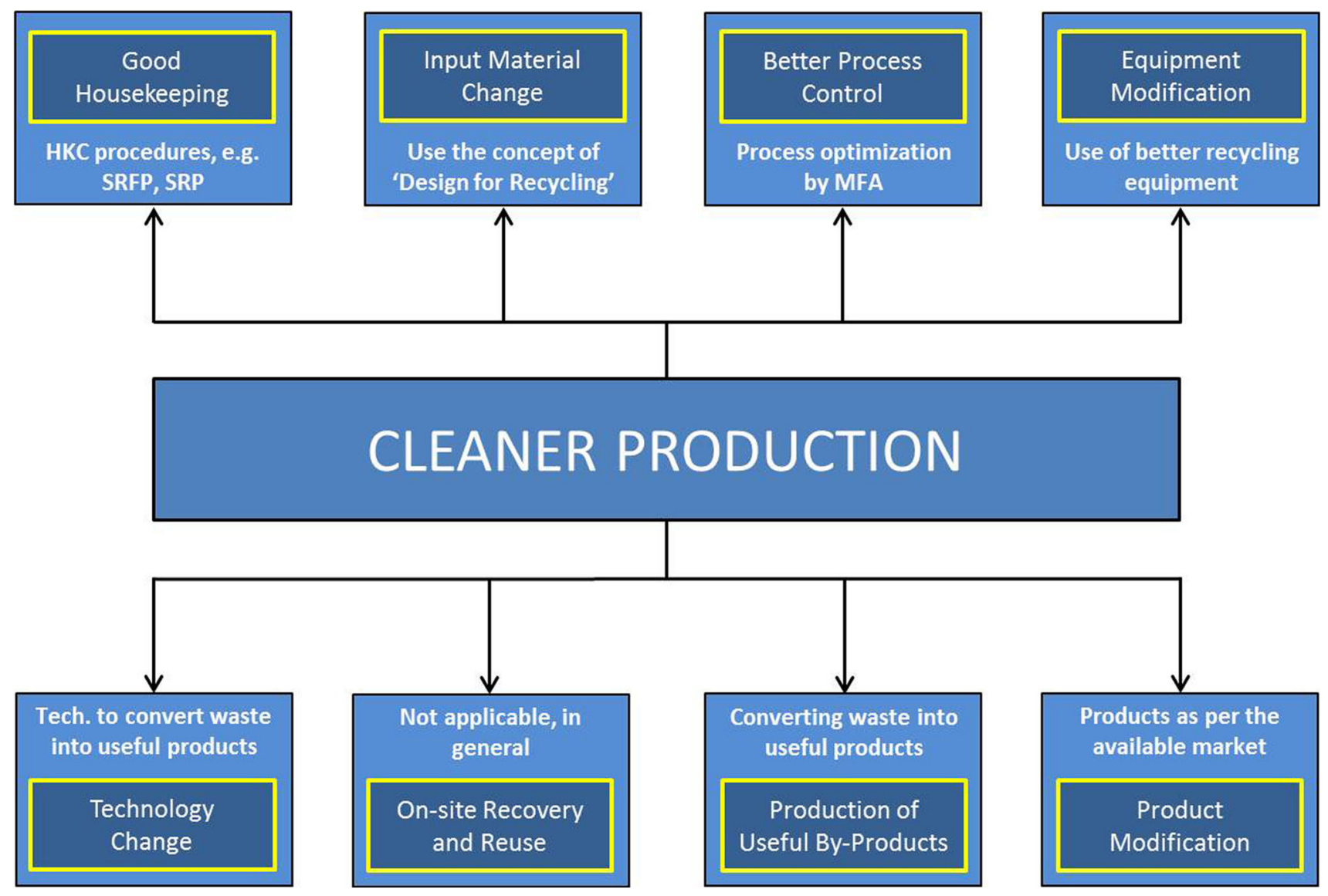

Fig. 2 Evaluation of applicability of cleaner production options to ship recycling Source: Author based on UNIDO-UNEP (2010), inner boxes describe the general $\mathrm{CP}$ options, and outer boxes describe the applicability of each option to ship recycling

5. Using well-established technology to convert waste generated at the ship recycling yards into useful products.

6. Producing products according to the market demand.

Most of the strategies are yard-based strategies as they are focused at bringing changes to the practices and procedures followed on a yard, except for design-for-recycling, which is a ship-based strategy as it is focused at changing the way ships are designed and built. The abovelisted ship recycling-related strategies generated by assessing the cleaner production options must be assessed for their usefulness in achieving the objectives of this research. They, as mentioned in the introduction, are to increase revenue, reduce costs and improve planning of the ship recycling process.

The results of evaluation of generic cleaner production options suggest that the objective of improving the planning of the ship recycling process can be fulfilled by implementing the procedures of the $\mathrm{HKC}$, such as preparing the SRFP and SRP. However, HKC does not provide specific guidelines or a framework to prepare such plans (Hiremath et al. 2016). This procedural gap can be filled by the analytical approach proposed in this paper, i.e. the material flow analysis. It can help recycling yards plan the ship recycling process in such a way that the costs are reduced and thus work towards fulfilling another dimension of improving their competitiveness. The use of MFA within the context of ship recycling and the role it can play in reducing the costs of the ship recycling process is explained in detail by the authors in Jain et al. (2017).

The evaluation results further suggest that the objective of increasing the revenue of the ship recycling process can be fulfilled by installing a waste-to-energy plant on the ship recycling yards so that an extra amount of earnings can be made by selling products created out of the waste. Some amount of savings can also be made due to reduced waste disposal costs by virtue of waste getting converted into energy and other useful products. The ship recycling yards can decide to offer a part of these extra earnings to ship owners in terms of improved offer price for buying EOL ships, which, in turn, will make such yards attractive to ship owners. In order to draw any conclusions on the feasibility of such a technology an extensive research must be carried out. This subject is explored by authors in Jain and Pruyn (2016), where they have discussed the economic 
Table 1 Strategies to achieve research objectives with respect to the cleaner production options

\begin{tabular}{llll}
\hline S. no & Cleaner production option & Strategy for ship recycling & Targeted research objective \\
\hline 1. & Better process control & Material flow analysis & Improved planning leading to reduced costs \\
2. & Input material change & Design-for-recycling & Reduced costs \\
3. & Technology change & Waste-to-energy technology & Increased revenue \\
4. & Production of useful by-products & Waste-to-energy technology & Increased revenue \\
\hline
\end{tabular}

feasibility of a plasma gasification plant on a large ship recycling yard. The impact of installing and operating such a plant on the offer price is also discussed in the same piece of research. However, a technical feasibility analysis must still be undertaken to draw some meaningful conclusions.

The evaluation results also suggest that the objective of reducing the costs of the ship recycling process can be achieved by applying the ship-based strategy, design-forrecycling. This concept is aimed at building ships that contain no hazardous materials and are easy to dismantle. The improvement in ship-related documents which can be useful during the ship's recycle phase, such as weights and inventory of materials used in ship construction, is also an important aspect of this concept. As discussed earlier, several studies have explored this subject. However, they are inadequate to obtain meaningful results for ship recycling, suggesting the need for further research.

The costs of the ship recycling process may also be reduced by employing certain operations management tool, for example, lean manufacturing, especially given the similarities of the ship recycling process with the production process. However, Jain et al. (2017) discussed that the unique challenges faced by the ship recycling industry make the implementation of the operations management tool rather ineffective. In spite of that, process optimization can certainly be useful. However, it depends on the willingness of the ship recycling yards to collect and analyse the relevant data. The willingness of a ship recycling yard is also required for implementing the other two yard-based strategies, i.e. the use of better recycling equipment and producing market-related products.

The discussion on the ship recycling-related cleaner production options indicates that the following three main strategies are promising to improve the competitiveness of the green ship recycling yards:

1. Material flow analysis to improve the planning of the ship recycling process, which in turn may reduce the costs of the process.

2. Use of proven waste-to-energy (WtE) technology to valorize the waste for increasing the revenue of the ship recycling yard.

3. Designing ships using the concept of design-forrecycling to reduce their structural complexity and to limit the use of hazardous materials assisting in lowering the costs of recycling.

The implementation of both the yard-based strategies (MFA and WtE) depends on quantifying the material streams originating from an EOL ship because the amount of materials to be handled by a yard must be known to analyse the flow of materials and to calculate the amount of waste generated. Therefore, a material quantification model is needed, which is presented by the authors in Jain et al. (2016b).

The ship-based strategy, design-for-recycling, will be able to show any improvements in the ship recycling process only 20-25 years after its implementation, once such ships start reaching the ship recycling yards at the end of their economic lives. Therefore, there is an urgent need to implement design-related strategies. In the meantime, green recycling yards must resort to other means, such as process optimization and planning, in order to reduce the costs of the ship recycling process.

The proposed strategies in relation to generic $\mathrm{CP}$ options and the research objectives are summarized in Table 1.

\section{Conclusion}

The application of the concept of cleaner production has resulted in identifying three strategies that can be used to improve the competitiveness of the green ship recycling. These strategies are material flow analysis to improve the planning of the ship recycling process, waste-to-energy technology to improve the earnings of a ship recycling yard and design-for-recycling to reduce the costs of the ship recycling process.

The proposed strategies are classified into two categories, yard-based strategies and ship-based strategies. Out of the three main strategies proposed in this paper, MFA and $\mathrm{WtE}$ are yard-based strategies, while design-for-recycling is a ship-based strategy. The implementation of the proposed concepts is likely to improve the industrial process of recycling ships, the productivity of the recycling activity and the profitability of operating a green SRF.

An in-depth research and analysis is needed to implement the suggested strategies on a ship recycling yard to 
improve its competitiveness. A detailed study is also required to determine the extent to which the suggested measures can bridge the gap between the prices offered by green SRF and substandard/non-green SRF. However, such analytical and feasibility studies are considered out of scope of this paper because it is focused only on describing a scientific framework which can help recycling yards identify the relevant measures to improve their competitiveness. To the best of our knowledge, no other authors have analysed any such framework specific to ship recycling. This proves the novelty and originality of this research, and at the same time, it also opens doors for other researchers to investigate the proposed strategies further.

Acknowledgements The authors of this article would like to acknowledge the support of Gieskes Strijbis Fonds for funding this research project on Green Ship Recycling, which is performed by Delft University of Technology, the Netherlands, in collaboration with Tianjin University, China, and International Ship Recycling Association (ISRA), the Netherlands.

Open Access This article is distributed under the terms of the Creative Commons Attribution 4.0 International License (http://crea tivecommons.org/licenses/by/4.0/), which permits unrestricted use, distribution, and reproduction in any medium, provided you give appropriate credit to the original author(s) and the source, provide a link to the Creative Commons license, and indicate if changes were made.

\section{References}

Alkaner S, Das PK, Smith DL, Dilok P (2006) Comparative analysis of ship production and ship dismantling. In: International conference on dismantling of obsolete vessels, Glasgow, UK

Baas LW (1995) Cleaner production: beyond projects. J Clean Prod 3:55-59. doi:10.1016/0959-6526(95)00042-D

Bonilla SH, Almeida CMVB, Giannetti BF, Huisingh D (2010) The roles of cleaner production in the sustainable development of modern societies: an introduction to this special issue. J Clean Prod 18:1-5. doi:10.1016/j.jclepro.2009.09.001

Cagno E, Trucco P, Tardini L (2005) Cleaner production and profitability: analysis of 134 industrial pollution prevention (P2) project reports. J Clean Prod 13:593-605. doi:10.1016/j.jclepro. 2003.12.025

Devault DA, Beilvert B, Winterton P (2016) Ship breaking or scuttling? A review of environmental, economic and forensic issues for decision support. Environ Sci Pollut Res. doi:10.1007/ s11356-016-6925-5

Dieleman H (2007) Cleaner production and innovation theory. Social experiments as a new model to engage in cleaner production. Rev Int Contam Ambient 23: 79-94. http://ref.scielo.org/zwdn7b

Dodić SN, Vučurović DG, Popov SD, Dodić JM, Zavargo ZZ (2010) Concept of cleaner production in Vojvodina. Renew Sust Energy Rev 14:1629-1634. doi:10.1016/j.rser.2010.02.004

Dorfman M, White A, Becker M, Jackson T (1993) Profiting from pollution prevention. In: Jackson $\mathrm{T}$ (ed) Cleaner production strategies: developing preventive environmental management in the industrial economy. Lewis Publishers, London, pp 189-206

Durham E, Hewitt A, Bell R, Russell S (2015) 7-technical design for recycling of clothing A2. In: Blackburn $\mathrm{R}$ (ed) Sustainable apparel. Woodhead Publishing, Cambridge, pp 187-198
El-Haggar SM (2007) Chapter 2-cleaner production, sustainable industrial design and waste management. Academic Press, Oxford, pp 21-84

EU (2013) Regulation (EU) no 1257/2013 of the European parliament and of the council of 20 November 2013 on ship recycling and amending regulation (EC) no 1013/2006 and directive 2009/16/ EC

Ferrão P, Amaral J (2006) Design for recycling in the automobile industry: new approaches and new tools. J Eng Des 17:447-462. doi:10.1080/09544820600648039

Fresner J (1998) Cleaner production as a means for effective environmental management. J Clean Prod 6:171-179. doi:10. 1016/S0959-6526(98)00002-X

Glavič P, Lukman R (2007) Review of sustainability terms and their definitions. J Clean Prod 15:1875-1885. doi:10.1016/j.jclepro. 2006.12.006

Hiremath AM, Pandey SK, Asolekar SR (2016) Development of shipspecific recycling plan to improve health safety and environment in ship recycling yards. J Clean Prod 116:279-298. doi:10.1016/ j.jclepro.2016.01.006

IMO (2009) Hong Kong international convention for the safe and environmentally sound recycling of ships. In: 2009, international conference on the safe and environmentally sound recycling of ships. IMO, Hong Kong

IMO (2012) Guidelines for safe and environmentally sound ship recycling. In: IMO (ed) Annex 4 resolution MEPC. 210(63)

Jackson T (2002) Industrial ecology and cleaner production. In: Ayres RU, Ayres LW (eds) A handbook of industrial ecology. Edward Elgar Publishing Ltd., Cheltenham, pp 36-43

Jacobsen NB (2006) Industrial symbiosis in Kalundborg, Denmark: a quantitative assessment of economic and environmental aspects. J Ind Ecol 10:239-255. doi:10.1162/108819806775545411

Jain KP, Pruyn J (2016) Economic impact assessment of using a plasma gasification plant on a large ship recycling yard. In: Clarke WP, Cossu R, Diaz LF, Liu J, Matsuto T, Nelles M, Stegmann R (eds) Venice 2016-sixth international symposium on energy from biomass and waste. CISA Publisher, Venice

Jain KP, Pruyn JFJ, Hopman JJ (2015) Influence of ship design on ship recycling. In: Soares CG, Santos TA (eds) Maritime technology and engineering-proceedings of MARTECH 2014: 2nd international conference on maritime technology and engineering, pp 269-276. http://dx.doi.org/10.1201/b17494-37

Jain KP, Pruyn JFJ, Hopman JJ (2016a) Improving ship design process to enhance ship recycling. In: Soares CG, Santos TA (eds) Maritime technology and engineering III-proceedings of MARTECH 2016: 3rd international conference on maritime technology and engineering, pp 663-671. http://dx.doi.org/10. 1201/b21890-86

Jain KP, Pruyn JFJ, Hopman JJ (2016b) Quantitative assessment of material composition of end-of-life ships using onboard documentation. Resour Conserv Recycl 107:1-9. doi:10.1016/j. resconrec.2015.11.017

Jain KP, Pruyn JFJ, Hopman JJ (2017) Material flow analysis (MFA) as a tool to improve ship recycling. Ocean Eng 130:674-683. doi:10.1016/j.oceaneng.2016.11.036

Kjaerheim G (2005) Cleaner production and sustainability. J Clean Prod 13:329-339. doi:10.1016/S0959-6526(03)00119-7

Kliopova I, Staniskis JK (2006) The evaluation of cleaner production performance in Lithuanian industries. $\mathrm{J}$ Clean Prod 14:1561-1575. doi:10.1016/j.jclepro.2005.04.017

Kuo TC (2010) The construction of a collaborative-design platform to support waste electrical and electronic equipment recycling. Robot Comput Integr Manuf 26:100-108. doi:10.1016/j.rcim. 2009.05.004

Larderel JAD (2002) Cleaner production seventh international highlevel seminar Prague. Ind Environ 25:5 
Lee KF (2001) Sustainable tourism destinations: the importance of cleaner production. J Clean Prod 9:313-323. doi:10.1016/S09596526(00)00071-8

Lopes Silva DA, Delai I, Soares de Castro MA, Ometto AR (2013) Quality tools applied to cleaner production programs: a first approach toward a new methodology. J Clean Prod 47:174-187. doi:10.1016/j.jclepro.2012.10.026

López-Gamero MD, Molina-Azorín JF, Claver-Cortés E (2010) The potential of environmental regulation to change managerial perception, environmental management, competitiveness and financial performance. J Clean Prod 18:963-974. doi:10.1016/j. jclepro.2010.02.015

McKenna SA, Kurt RE, Turan O (2012). A methodology for a 'design for ship recycling'. In: Royal institution of naval architectsinternational conference on the environmentally friendly ship. RINA, London, pp 37-44

Nilson L, Persson PO, Rydén L, Darozhka S, Zaliauskiene A (2007) Cleaner production: technologies and tools for resource efficient production. The Baltic University Press, Uppsala

Perry N, Bernard A, Laroche F, Pompidou S (2012) Improving design for recycling-application to composites. CIRP Ann Manuf Technol 61:151-154. doi:10.1016/j.cirp.2012.03.081

Petek J, Glaviç P (2000) Improving the sustainability of regional cleaner production programs. Resour Conserv Recycl 29:19-31. doi:10.1016/S0921-3449(99)00051-8

Sarraf M (2010) The ship breaking and recycling industry in Bangladesh and Pakistan. World Bank, Washington, D.C.

Severo EA, Guimarães JCFD, Dorion ECH (2017) Cleaner production and environmental management as sustainable product innovation antecedents: a survey in Brazilian industries. J Clean Prod. doi:10.1016/j.jclepro.2016.06.090

Sivaprasad K, Nandakumar CG (2013) Design for ship recycling. Ships Offshore Struct 8:214-223. doi:10.1080/17445302.2012. 669264

Soo VK, Compston P, Doolan M (2015) Interaction between new car design and recycling impact on life cycle assessment. Procedia CIRP 29:426-431. doi:10.1016/j.procir.2015.02.055
Sujauddin M, Koide R, Komatsu T, Hossain MM, Tokoro C, Murakami S (2017) Ship breaking and the steel industry in Bangladesh: a material flow perspective. J Ind Ecol. doi:10.1111/ jiec. 12423

Tian J, Chen M (2014) Sustainable design for automotive products: dismantling and recycling of end-of-life vehicles. Waste Manag 34:458-467. doi:10.1016/j.wasman.2013.11.005

Tseng M-L, Chiu ASF, Lin Y-H, Chinag J-H (2006) The relationship of continuous improvement and cleaner production on operational performance: an empirical study in electronic manufacturing firms, Taiwan China. Int J Manag Sci Eng Manag 1:71-80. doi:10.1080/17509653.2006.10670999

UNIDO-UNEP (2010) Taking stock and moving forward: the UNIDO-UNEP national cleaner production centres. UNEP, UNIDO; State Secretariat for Economic Affairs, Government of Switzerland, Vienna

Unnikrishnan S, Hegde DS (2007) Environmental training and cleaner production in Indian industry - a micro-level study. Resour Conserv Recyl 50:427-441. doi:10.1016/j.resconrec. 2006.07.003

Van Berkel R (2000a) Cleaner production for process industries: overview of the cleaner production concept and relation with other environmental management strategies. In: Barton ACT (ed) Chemeca 2000: opportunities and challenges for the resource and processing industries. Institution of Engineers, Australia, p 12

Van Berkel R (2000b) Cleaner production in Australia: revolutionary strategy or incremental tool? Aust J Environ Manag 7:132-146. doi:10.1080/14486563.2000.10648495

van Schaik A, Reuter MA (2004) The optimization of end-of-life vehicle recycling in the European union. JOM 56:39-43. doi:10. 1007/s11837-004-0180-9

Zeng SX, Meng XH, Yin HT, Tam CM, Sun L (2010) Impact of cleaner production on business performance. J Clean Prod 18:975-983. doi:10.1016/j.jclepro.2010.02.019 